\title{
The predictive value of amniotic fluid index for adverse perinatal outcome and suggested plan of action
}

\author{
Ritu Bawa*, Neerja
}

Department of Obstetrics and Gynecology, Muzaffarnagar Medical College, Muzaffarnagar, Uttar Pradesh, India

Received: 17 April 2017

Revised: 27 April 2017

Accepted: 18 May 2017

\section{*Correspondence:}

Dr. Ritu Bawa,

E-mail: ritu1.bawa@gmail.com

Copyright: (c) the author(s), publisher and licensee Medip Academy. This is an open-access article distributed under the terms of the Creative Commons Attribution Non-Commercial License, which permits unrestricted non-commercial use, distribution, and reproduction in any medium, provided the original work is properly cited.

\begin{abstract}
Background: Modern obstetrics and perinatal medicine is concerned with recognition of a fetus at risk for death or damage in utero: quantifying the risk and determining the optimal time and mode of intervention. Objective of present study was to determine whether an antepartum amniotic fluid index (AFI) of $5.0 \mathrm{~cm}$ or less is a predictor of adverse perinatal outcome.

Methods: This was a prospective study of 400 antenatal women booked at Muzaffarnagar Medical College during the year 2015-16 with gestational age between 36 and 41 weeks AFI was determined using the Phelan's technique within 7 days of delivery or at the onset of labour. Perinatal outcome was compared between two groups i.e. AFI $\leq 5$ and $>5$.

Results: An AFI of $5.0 \mathrm{~cm}$ or less was significantly associated with higher cesarean section rate for fetal distress and low birth weight babies. There was no significant difference in APGAR score at $5 \mathrm{~min}$. $<7$ between the two groups.

Conclusions: Determination of AFI is valuable for predicting fetal distress in labour requiring cesarean section. It can be used as an adjacent to other fetal surveillance methods. An AFI $<5$ detected after 36 weeks of gestation is an indicator of poor perinatal outcome.
\end{abstract}

Keywords: Amniotic fluid index, APGAR score, Cesarean delivery, Non-stress test

\section{INTRODUCTION}

Modern obstetrics and perinatal medicine is concerned with recognition of a fetus at risk for death or damage in utero: quantifying the risk and determining the optimal time and mode of intervention. Clinical estimation of amniotic fluid volume (AFV) is an important part of fetal assessment as variation in its amount has been related to a variety of pregnancy complications.

Amniotic fluid provides the fetus with a protective low resistance environment suitable for growth and development.In some cases the amniotic fluid may measure two low or too high. ${ }^{1}$ In 1987 Phelan et al described a four quadrant method of assessing AFI. ${ }^{2}$
Using that technique an AFI of $5 \mathrm{~cm}$ or less is defined as oligohydrominos. Quantification of amniotic fluid is an important component of the biophysical profile in ultrasound evaluation of fetal wellbeing especially in the third trimester.

Links have been found between decreased amniotic fluid volume and the non-reactive non-stress tests, FHR declarations, cesarean sections for fetal distress and low APGAR scores. ${ }^{3,4}$

Keeping in mind the present study was carried out to fluid whether oligohydraminios can be used as a predictor of adverse perinatal outcome in non-complicated pregnancies at term. 


\section{METHODS}

The present study was a prospective study carried out at Muzaffarnagar Medical College, Muzaffarnagar. The study participants included 400 booked antenatal women registered at Muzaffarnagar Medical College \& Hospital, Muzaffarnagar between 36 and 41 weeks admitted for delivery over a 2 year duration from 2014 to 2016 .

\section{Inclusion criteria}

- $\quad$ Single non-anomalus fetus

- Intact membranes.

\section{Exclusion criteria}

- Ruptured membranes

- Fetal anamoly

- Gestational diabetes

- Rh incompatibility

- Multiple pregnancies

On admission, a detailed history was taken and a clinical examination was performed. Amniotic fluid index was determined using the Phelan's technique within 7 days of delivery or at the onset of labour. Non-stress test (NST) was performed for all patients. Women were divided into two groups based on their AFI: Group - 1: AFI $\leq 5$; Group 2 - AFI >5. A note was made of mode of delivery, birth weight APGAR score at 1 and 5 minutes. The results were recorded and tabulated. They were statistically analyzed using Chi-Square test.

\section{RESULTS}

Out of the 400 women the mean maternal age was 27.67 in group 1 and 26.07 in group 2, out of which $46(67.6 \%)$ were nulliparous in group 1 and $199(59.9 \%)$ in group 2 .

Table 1: Maternal demographic obstetric characteristics.

\begin{tabular}{|llll|}
\hline & $\begin{array}{l}\text { AFI }<5 \\
(\mathbf{n = 6 0 )}\end{array}$ & $\begin{array}{l}\text { AFI }>5 \\
(\mathbf{n = 3 3 2})\end{array}$ & P value \\
\hline $\begin{array}{l}\text { Maternal Age } \\
(\text { mean })\end{array}$ & 27.67 & 26.07 & \\
\hline Nullilparity & $\begin{array}{l}46 \\
(67.6 \%)\end{array}$ & $\begin{array}{l}199 \\
(59.9 \%)\end{array}$ & 0.2353 \\
\hline $\begin{array}{l}\text { Gestational age }<38 \\
\text { weeks at delivery) }\end{array}$ & $\begin{array}{l}38 \\
(55.9 \%)\end{array}$ & $\begin{array}{l}114 \\
(34.3 \%)\end{array}$ & 0.0009 \\
\hline $\begin{array}{l}\text { Weight gain } \\
<10 \mathrm{Kg}\end{array}$ & $\begin{array}{l}25 \\
(36.8 \%)\end{array}$ & $\begin{array}{l}28 \\
(8.4 \%)\end{array}$ & $<0.0001$ \\
\hline Induction of labour & $\begin{array}{l}49 \\
(72.1 \%)\end{array}$ & $\begin{array}{l}169 \\
(50.9 \%)\end{array}$ & 0.0015 \\
\hline
\end{tabular}

Gestational age was < 38 weeks in $38(55.9 \%)$ in group 1 as compound to $114(34.3 \%)$ in group 2. Maternal weight gain during pregnancy was $<10 \mathrm{~kg}$ in $25(36.8 \%$ ) in group 1 as compared to $28(8.4 \%)$ in group 2.49 patients
(72.1\%) were induced in group 1 as compared to 169 $(50.9 \%)$ in group 2. Obstetrics and perinatal outcome were studied in both the groups.

Table 2: Association of NST with oligohydraminos.

\begin{tabular}{|llll|}
\hline NST & Oligo & Normal & P \\
Reactive & AFI $<5$ & AFI $>5$ & Value \\
\hline Non-reactive & $30(44.1 \%)$ & $300(90.4 \%)$ & 0.0005 \\
\hline & 68 & 332 & 0.0001 \\
\hline
\end{tabular}

Table 2 shows that non-reactive NST was present in a significant number of patients in group $1(55.9 \%)$ as compared to group $2(9.6 \%)(\mathrm{P}<0.001)$.

Table 3: Mode of delivery according to AFI.

\begin{tabular}{|lcll|}
\hline $\begin{array}{l}\text { Mode of } \\
\text { delivery }\end{array}$ & AFI $<5$ & AFI $>5$ & $\begin{array}{l}\text { P } \\
\text { value }\end{array}$ \\
\hline $\begin{array}{l}\text { Total cesarean } \\
\text { delivery }\end{array}$ & $30(44.1 \%)$ & $105(31.9 \%)$ & 0.0479 \\
\hline $\begin{array}{l}\text { Cesarean for } \\
\text { non-reassuring } \\
\text { fetal stress }\end{array}$ & $17(56.6 \%)$ & $40(38.1 \%)$ & 0.0056 \\
$\begin{array}{l}\text { Normal } \\
\text { delivery }\end{array}$ & $38(55.9 \%)$ & $226(68.1 \%)$ & 0.0481 \\
\hline
\end{tabular}

Cesarean section was performed in 38(55.9\%) women in group 1 as compared to $106(31.92 \%)$ in group 2. A chi square statistic test was carried out to determine the significance of correlation between the AFI and mode of delivery. A p value was obtained which was less than 0.05 . This indicated the presence of a very strong and significant correlation between the AFI and mode of delivery.

Table 4: Perinatal outcomes.

\begin{tabular}{|llll|} 
& $\begin{array}{l}\text { AFI } \\
(\mathbf{n = 6 8})\end{array}$ & $\begin{array}{l}\text { AFI }>5 \\
(\mathbf{n = 3 3 2})\end{array}$ & P value \\
\hline $\begin{array}{l}\text { Birth weight } \\
(<2.5 \mathrm{~kg})\end{array}$ & $38(55.9 \%)$ & $72(21.7 \%)$ & $<0.0001$ \\
\hline $\begin{array}{l}\text { APGAR Score } \\
1 \text { min }<7\end{array}$ & $24(35.3 \%)$ & $36(10.8 \%)$ & $<0.0001$ \\
\hline $5 \min <7$ & $3(4.4 \%)$ & $11(3.3 \%)$ & 0.6536 \\
\hline
\end{tabular}

Birth weight $<2.5 \mathrm{~kg}$ was found in $38(55.9 \%)$ patients in group 1 as compared to $72(21.7 \%)$ in group 2. In Group 1 the APGAR score at $1 \mathrm{~min}$ was $<7$ in 24 women $(35.3 \%) \mathrm{j}$ as compared to $36(10.8 \%)$ in group $2(\mathrm{P}=$ $<0.0001)$. An APGAR score $<7$ at 5 min was noted in 3 $(4.4 \%)$ women in group 1 and $11(3.3 \%)$ women in group $2(\mathrm{P}=0.6536)$.

\section{DISCUSSION}

The non-reactive NST rates are high in women with AFI $<5 \mathrm{~cm}$. The rate of non-reactive NST is $55.9 \%$. This is in accordance with the study by Chandra et al, Sriya et al 
and Kumar et al with $69.23 \%, 41.55 \%$ and $40 \%$ respectively. ${ }^{5-7}$ These studies show that more than half of the patients with $\mathrm{AFI}<5$ have non-reactive NST.

Various studies show different rates of LSCS for fetal distress in pregnant woman with AFI $<5 \mathrm{~cm}$. The LSCS for fetal distress was $76.92 \%, 51 \%$ and $43.05 \%$ in studies done by Chandra et al, Casey et al and Sriya et al respectively. ${ }^{5,6,8}$ It was $56.6 \%$ in present study Rutherford et al found an inverse relationship between amniotic fluid index and cesarean section for fetal distress. ${ }^{9}$

In the current study birth weight $<2.5 \mathrm{~kg}$ was found in $38(55.9 \%)$ group 1versus $72(21.7 \%)$ in group 2, the difference being statistically significant $(\mathrm{p}<0.0001)$. Morreset al found that $60 \%$ of babies were of LBW in the group with $\mathrm{AFI}<5$, indicating that oligohydraminos had an association with growth restriction. ${ }^{10} \mathrm{~A}$ study by Rutherford et al showed that when the AFI was $<5,36 \%$ pregnancies resulted in infants with intra uterine growth restriction (IUGR). ${ }^{9}$

In the present study, the 1 min APGAR Score was $<7$ in $24(35.3 \%)$ babies in group 1 whereas only $72(10.8 \%)$ babies in group 2 had 1 min APGAR Score $<7$ and this difference was statistically significant $(\mathrm{P}<0.0001)$.

However, the 5 min APGAR Score $<7$ was almost equal in both the groups (4.4 vs $3.3 \%)(\mathrm{p}=0.6536)$.

A study by Grubb et al $^{11}$ found the 1 min APGAR score $<7$ in $84 \%$ patients with AFI $<5$ as compared to $14 \%$ in the normal AFI group which was highly significant. In the same study the 5 min APGAR score $<7$ was seen in $13 \%$ patients with AFI $<5$ versus $5 \%$ in the normal AFI group.

\section{CONCLUSION}

An AFI of $<5 \mathrm{~cm}$ detected after 36 completed weeks of gestation in a low risk pregnancy is an indicator of poor perinatal outcome. In presence of oligohydroamnios, the occurrence of non-reactive NST, abnormal FHR tracings during labour, development of fetal distress, the rate of LSCS, low 1 min APGAR score and perinatal mortality are high. Determination of AFI should be used as an adjunct to other fetal surveillance method. Continuous antepartum and intrapartum monitoring are mandatory for every woman diagnosed with oligohydroamnios to reduce the maternal and neonatal risks.

Funding: No funding sources Conflict of interest: None declared
Ethical approval: The study was approved by the Institutional Ethics Committee

\section{REFERENCES}

1. Bhagat M, Chawla I. Correlation of amniotic fluid index with perinatal outcome. Ind J Obstet Gynecol. 2014;64(1):32-5.

2. Phelan JP, Smith CV, Broussard P, Small M. Amniotic fluid volume assessment with the four quadrant technique at $36-42$ weeks gestation. J Reprod Med. 1987;32:540-2.

3. Locatelli A, Vergani P, Toso L, Verderio M, Pezzullo JC, Ghidini A. Perinatal outcome associated with oligohydramnios in uncomplicated term pregnancies. Arch Gynecol Obstet. 2004;269:130-3.

4. Murray $\mathbf{M}$ editor. Antepartal fetal monitoring. In: antepartal and intrapartal fetal monitoring. New York: Springer Publishing Company; 2006:455-87.

5. Chandra P, Kaur SP, Hans DK, Kapika AK. The impact of amniotic fluid volume assessed intrapartum on perinatal outcome. Obstet Gynecol Today. 2000;5:478-81.

6. Sriya $R$, Singhai S. Perinatal outcome in patients with amniotic fluid index $\leq 5 \mathrm{~cm}$. J Obstet Gynecol India. 2001;51:98-100.

7. Kumar P, Iyer S, Ramkumar V. Amniotic fluid index: a new ultrasound assessment of amniotic fluid. J Obstet Gynecol India. 1991;41:10-2.

8. Casey BM, Mctire DD, Bloom SL, Lucas MJ, Santos $\mathrm{R}$, Twickler DM et al. Pregnancy outcome after antepartum diagnosis of oligohydramnios at or beyond 34 weeks gestation. Am J Obstet Gynecol. 2000;1982:909-12.

9. Rutherford SE, Phelan JP, Smith CV, Jacobs N. The four quadrant assessment of amniotic fluid volume: an adjunct to antepartum fetal heart rate testing. Obstet Gynecol. 1987;70(3):353-6.

10. Morries JM, Thompson K, Smithey J Gaffney G, Cooke I, Chamberlain $\mathrm{P}$ et al. The usefulness of ultrasound assessment of amniotic fluid in predicting adverse outcome in prolonged pregnancy: a prospective blinded observational study. Br J Obstet Gynecol. 2003;110(11): 989-94.

11. Grubb DK, Paul RH. Amniotic fluid index and prolonged antepartum fetal heart rate declaration. Obstet Gynaecol, 1992; 79(4); 558-60.

Cite this article as: Bawa R, Neerja. The predictive value of amniotic fluid index for adverse perinatal outcome and suggested plan of action. Int $\mathrm{J}$ Reprod Contracept Obstet Gynecol 2017;6:2952-4. 